\title{
FEEDING BIOLOGY OF A GUILD OF BENTHIVOROUS FISHES IN A SANDY SHORE ON SOUTH-EASTERN BRAZILIAN COAST
}

\author{
ZAHORCSAK, P., ${ }^{1}$ SILVANO, R. A. M. ${ }^{2}$ and SAZIMA, I. ${ }^{1}$ \\ ${ }^{1}$ Departamento de Zoologia and Museu de História Natural, Universidade Estadual de Campinas, C.P. 6109, \\ CEP 13083-970, Campinas, São Paulo, Brazil \\ ${ }^{2}$ Núcleo de Estudos e Pesquisas Ambientais, Universidade Estadual de Campinas, C.P. 6166, CEP 13081-970, \\ Campinas, São Paulo, Brazil \\ Correspondence to: Renato A. M. Silvano, Núcleo de Estudos e Pesquisas Ambientais, Universidade Estadual de \\ Campinas, C.P. 6166, CEP 13081-970, Campinas, São Paulo, Brazil, e-mail: silvano@nepam.unicamp.br \\ Received May 14, 1999 - Accepted November 17, 1999 - Distributed August 31, 2000
}

(With 3 figures)

\begin{abstract}
The feeding biology of eight species of benthivorous fishes was studied in a sandy shore at Anchieta Island, south-eastern Brazilian coast. The fishes fed mainly on Amphipoda and Mysidacea crustaceans. The diet of the most abundant species, the drum Umbrina coroides, was analyzed in three standard length classes (20-55, 56-90 and 91-135 mm). This sciaenid showed an ontogenetic diet shift from Mysidacea to Amphipoda. The feeding behaviour of the sciaenid U. coroides and the gerreid Eucinostomus gula was recorded while snorkeling. During their foraging both species uncovered small organisms buried in the sand. Notwithstanding general similarities in diet, U. coroides and E. gula presented differences in feeding behaviour and morphology. Two carangid species of the genus Trachinotus differed in diet composition and consumed a larger array of food items than the remaining fish species. Differences in diet and feeding activity between the remaining benthivorous species were noted. These differences possibly reduce overlap in resource use and favour the coexistence of guilds of benthivorous fishes on sandy shores.
\end{abstract}

Key words: marine fishes, ontogenetic diet shift, Umbrina coroides, Eucinostomus gula.

\section{RESUMO}

\section{Hábitos alimentares de uma guilda de peixes bentívoros em uma praia arenosa na costa Sudeste do Brasil}

Os hábitos alimentares de oito espécies de peixes bentívoros foram estudados em uma praia arenosa na Ilha Anchieta, costa Sudeste do Brasil. Os peixes consumiram principalmente crustáceos das ordens Amphipoda e Mysidacea. A dieta da espécie mais abundante, o sciaenídeo Umbrina coroides, foi analisada em três classes de comprimento-padrão (20-55, 56-90 e 91-135 mm). Este sciaenídeo apresentou uma variação ontogenética na dieta, a qual variou de Mysidacea para Amphipoda. O comportamento alimentar do sciaenídeo $U$. coroides e do gerrídeo Eucinostomus gula foi estudado com uso de mergulho livre. Ao forragear, ambas as espécies desenterraram pequenos organismos enterrados na areia. Apesar das semelhanças gerais na dieta, U. coroides e E. gula apresentaram diferenças quanto ao comportamento alimentar e morfologia. Duas espécies de carangídeos do gênero Trachinotus diferiram quanto à composição da dieta e consumiram variedade maior de itens alimentares que as outras espécies de peixes estudadas. Diferenças de dieta e atividade alimentar entre as outras espécies bentívoras foram registradas. Estas diferenças possivelmente reduzem a sobreposição na utilização dos recursos alimentares, favorecendo a coexistência de guildas de peixes bentívoros em praias arenosas.

Palavras-chave: peixes marinhos, variação ontogenética na dieta, Umbrina coroides, Eucinostomus gula. 


\section{INTRODUCTION}

Morphological and behavioral traits related to prey capture and predator avoidance regulate predator-prey interactions, thus influencing the structure of fish communities (Lowe-McConnell, 1977, 1987). Many fish species, especially when juveniles, inhabit sandy coastal areas, where they gather food and shelter from large predators (LoweMcConnell, 1977). Benthivorous fishes present the greatest diversity of feeding modes among fishes (Gerking, 1994), external morphology related to foraging behaviour and predator avoidance, and exploit efficiently soft substrates such as sandy shores (Hobson \& Chess 1986; McCormick, 1995; Platell et al., 1998). These fishes usually have sensorial appendices and inferior protractile mouths (Chao \& Musick, 1977; Gerking, 1994), and prey on benthic invertebrates near or on the bottom, burying the mouth into the substrate and swallowing part of the sediment (Hobson \& Chess, 1986; Sazima, 1986; Soares et al., 1993; Edgar \& Shaw, 1995). Differences in behaviour, habitat and time of feeding, as well as kind and size of prey, may reduce dietary overlap among benthivorous fishes (Hobson \& Chess, 1986; McCormick, 1995; Platell et al., 1998). In spite of the value of underwater observations for an insight on fish behaviour ( Longhurst, 1981; Sazima, 1986), very few underwater studies deal with marine sandy shores fishes (e.g., Hobson \& Chess, 1986). In this paper we present data on feeding biology of a guild of eight species of benthivorous fishes in a Brazilian sandy shore. Also, the feeding behaviour of two of the most abundant species, the sciaenid Umbrina coroides (Cuvier, 1830) and the gerreid Eucinostomus gula (Cuvier, 1830), is described.

\section{MATERIAL AND METHODS}

\section{Study site}

Field work was carried out at the Palmas sandy shore, Anchieta Island, south-eastern Brazilian coast $\left(23^{\circ} 32^{\prime} \mathrm{S}, 45^{\circ} 04^{\prime} \mathrm{W}\right)$. Anchieta Island is a marine park, and the Palmas shore fringes a bay of about $400 \mathrm{~m}$ (see Soares et al., 1993 for map and general description of study area).

\section{Underwater observations}

Feeding behaviour of $U$. coroides $(27 \mathrm{~min}$ of observation) and E. gula (38 min of observation) was recorded while snorkeling in shallow water (0.5-2 m depth), using "focal animal" and "all occurrences" samplings (Lehner, 1979) in a total of $30 \mathrm{~h}$. Swimming slowly along the shore, we observed one individual at a time, and recorded behavioral events in a plastic slate. The number of bites on the sandy substrate per minute was recorded, and the results for the two species was compared using the $\mathrm{t}$ - test.

\section{Sampling methods}

Fishes were collected along the shore using a $10 \times 1.5 \mathrm{~m}$ dragnet with $20 \mathrm{~mm}$ mesh size, in a depth ranging 1-1.5 m, from January through March, and July, November and December of 1997. We collected during morning and afternoon, in order to obtain information from both diurnal feeding periods (Hobson \& Chess, 1986). Stomach contents were examined under stereomicroscope and food items were identified to order or class (Chao \& Musick, 1977; Sazima, 1986). Voucher specimens of fishes and their gut contents are in the fish collection of the Museu de Historia Natural, Universidade Estadual de Campinas (ZUEC 33663379). For each food item we calculated occurrence (F\%) and numerical (N\%) frequencies (Hyslop, 1980; Marrero, 1994). We classified as main food items those where F\% > 50\% following Soares et al. (1993). The degree of stomach fullness (f) was estimated visually, considering four categories: empty, $0 \%<\mathrm{f}<=25 \%$; moderate, $25 \%<\mathrm{f}<=$ $50 \%$; full, $50 \%<\mathrm{f}<=75 \%$; and replete $75 \%<$ $\mathrm{f}<=100 \%$. Stomach fullness degree of the four most abundant fish species was analyzed in two periods, morning (6:00-12:00 h) and afternoon (12:00-18:00 h). The diet of the most abundant fish species, $U$. coroides, was analyzed in three standard length classes, in order to verify possible ontogenetic changes in diet according to the species grow.

\section{RESULTS}

\section{Feeding behaviour}

Individuals of $U$. coroides and $E$. gula foraged alone over the bottom, repeatedly exploiting selected sites, approximately circular (about 40 $\mathrm{cm}$ in diameter). Both species searched for prey swimming in circles, apparently selecting the sites where they would forage and the substrate which they would bite. Umbrina coroides $(7.9 \pm 1.9$ bites 
per minute) fed more frequently than E. gula (4 \pm 1.6 bites per minute, $\mathrm{t}_{0.05}=3.6647, \mathrm{p}<0.01$ ). Umbrina coroides swam about $1-2 \mathrm{~cm}$ above the bottom, and stopped at a given site (Fig. 1a). With its body slightly prone, about $15^{\circ}$ or $20^{\circ}$, the fish buried its mouth into the sand (Fig. 1b) and ejected sediment through its mouth and gill openings, producing a dense sandy cloud (Fig. 1c). Eucinostomus gula swam about $3-4 \mathrm{~cm}$ above the bot- tom, watching intently at the sandy substrate and stopping at a given site (Fig. 1a). Tilting its body about $45^{\circ}$, the fish protruded its mouth and buried it into the sand (Fig. 1b) and ejected sediment through its mouth and gill openings, producing a scattered sandy cloud of thin sediment (Fig. 1c). Umbrina coroides produced a round shallow hole in the sand, whereas E. gula produced an irregular and deeper one.
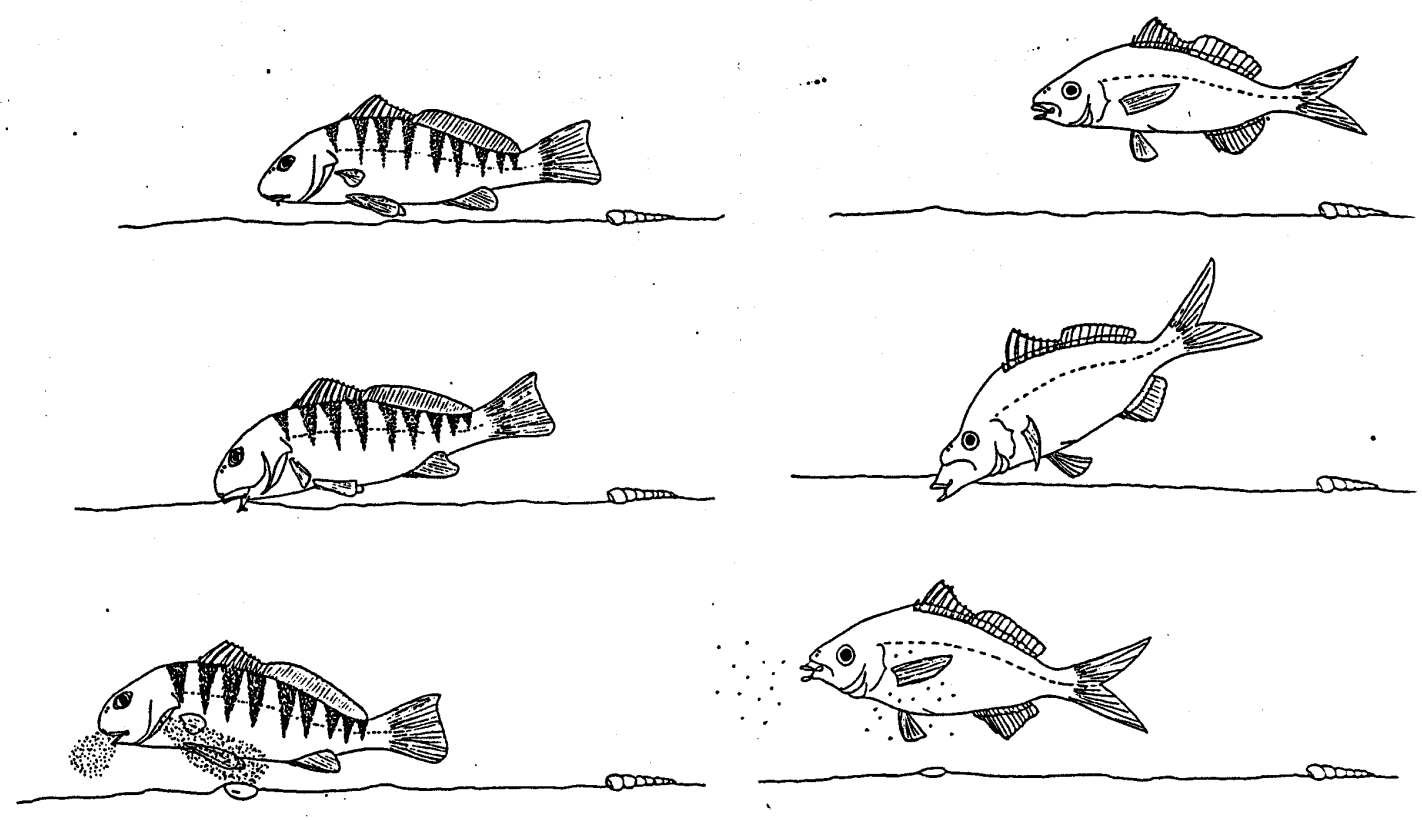

Fig. 1 - Feeding behaviour of Umbrina coroides (left) and Eucinostomus gula (right). Swimming near the bottom (a), burying mouth in the sand (b), ejecting sediment through mouth and gill openings (c).

\section{Diet}

From the eight species of benthivorous fishes (Fig. 2), the sciaenid Umbrina coroides was the most abundant $(n=63$ individuals, $47 \%$ of fish caught). Main food items were Amphipoda and Mysidacea crustaceans. We split the former in two distinct unidentified categories, Amphipoda 1 and 2. The sciaenid Menticirrhus littoralis (Holbrook, 1855) (standard length, $\mathrm{SL}=43-92 \mathrm{~mm}, \mathrm{n}=6$ ) and the gerreid Eucinostomus gula $(\mathrm{SL}=67-149$ mm, $\mathrm{n}=21$ ) preyed mostly on Amphipoda 1, whereas the carangid Trachinotus falcatus (Linnaeus, 1758) $(\mathrm{SL}=36-48 \mathrm{~mm}, \mathrm{n}=3)$ and the haemulid Orthopristis ruber (Cuvier, 1830) (SL $=47-61 \mathrm{~mm}$, $\mathrm{n}=3$ ) consumed mostly Amphipoda 2. The sciaenid Ophioscion punctatissimus Meek \& Hildebrand, 1925 (SL = 32-73 mm, $\mathrm{n}=5$ ) fed mainly on Mysidacea, whereas $U$. coroides $(\mathrm{SL}=27-134$ $\mathrm{mm}, \mathrm{n}=63$ ) preyed on two main items, Amphipoda 1 and Mysidacea. 

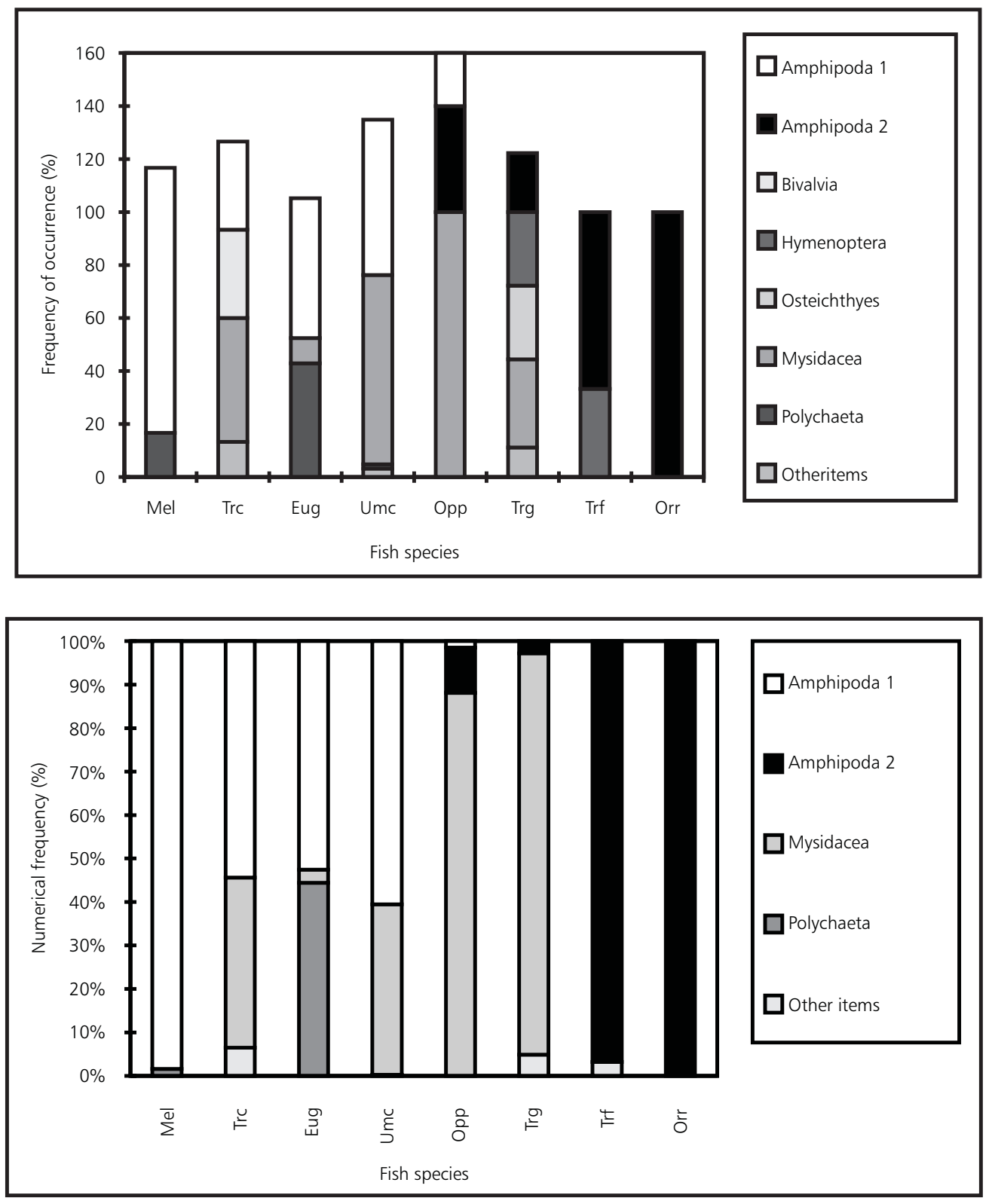

Fig. 2 - Frequency of occurrence (\%) and numerical frequency (\%) of food items in the diet of a guild of benthivorous fishes from Anchieta Island: Menticirrhus littoralis (Mei), Trachinotus carolinus (Trc), Eucinostomus gula (Eug), Umbrina coroides (Umc), Ophioscion punctatissimus (Opp), Trachinotus goodei (Trg), Trachinotus falcatus (Trf), Orthopristis ruber (Orr).

Two congener carangids, Trachinotus goodei Jordan \& Evermann, $1896(\mathrm{SL}=30-167 \mathrm{~mm}, \mathrm{n}=$ 18) and Trachinotus carolinus (Linnaeus, 1766) (SL = 41-85 mm, $\mathrm{n}=15$ ), differed in diet composition and consumed a greater array of food items than the remaining benthivorous species. The numerical frequency follows the same general pattern described above for the frequency of occurrence (Fig. 2). A greater proportion of individuals with full and replete stomachs was recorded during the morning for $U$. coroides $(30.6 \%)$ and E. gula (4\%), and during the afternoon for $T$. goodei $(34.9 \%)$ and T. carolinus $(15.8 \%)$. 


\section{Ontogenetic changes in diet}

Ontogenetic diet shift was recorded for the sciaenid $U$. coroides. Small individuals ( $\mathrm{SL}=20$ $55 \mathrm{~mm}$ ) fed almost exclusively on Mysidacea, with numerical frequency of this prey dropping progressively in fishes larger than $56 \mathrm{~mm}$, and being partly replaced by Amphipoda (Fig. $3)$.
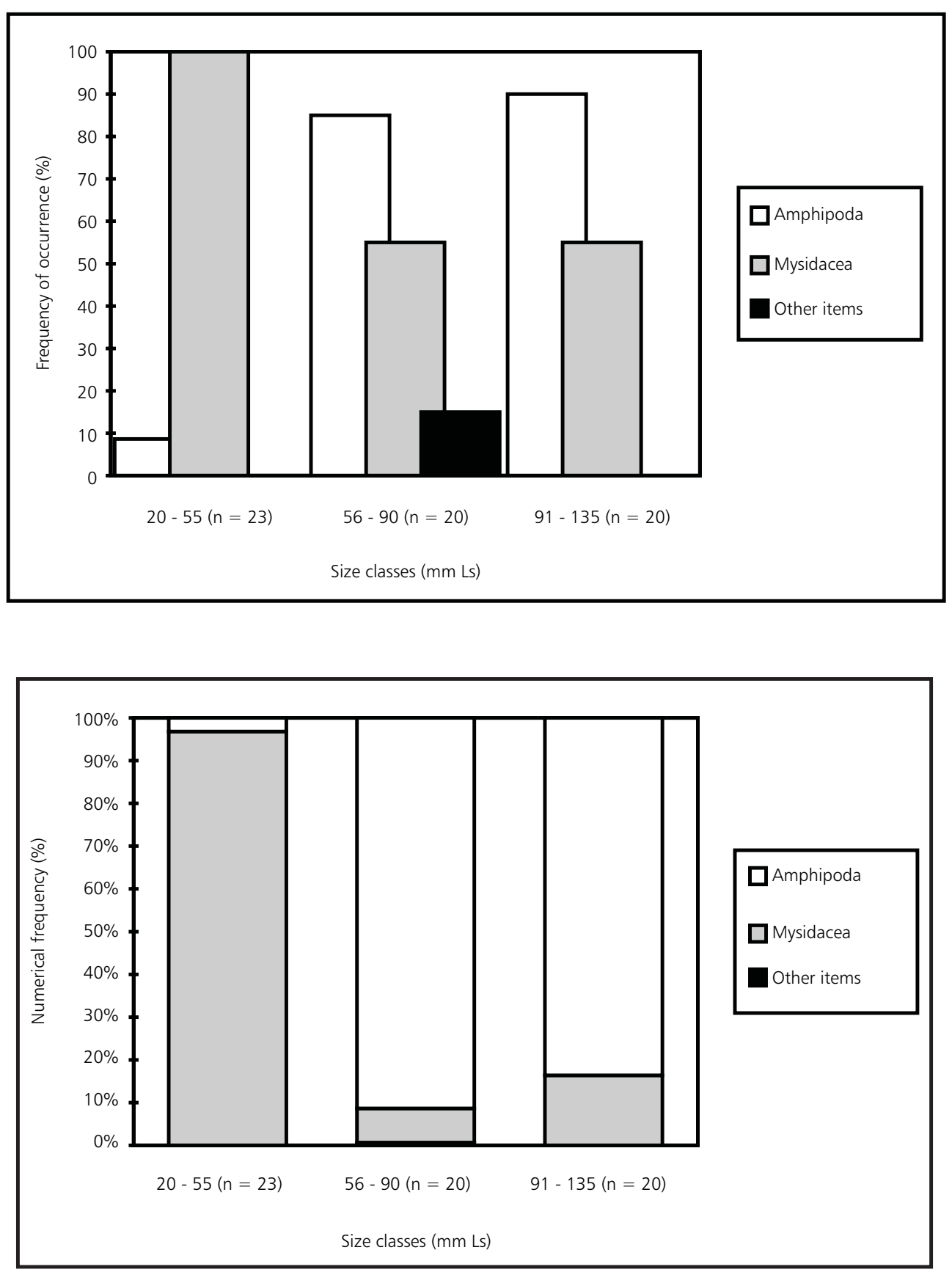

Fig. 3 - Frequency of occurrence (\%) and numerical frequency (\%) of food items in the diet of three size classes of Umbrina coroides. 


\section{DISCUSSION}

The feeding behaviour repertoires of $U m$ brina coroides and Eucinostomus gula are directed to uncover small organisms in the sandy substrate. Both fishes may be classified as diggers of localized excavations (Sazima, 1986).

Notwithstanding general similarities in their diets, these two fishes present differences in feeding behaviour and morphology.

Eucinostomus gula has a more tubular, protractile mouth and spends more time inspecting visually the substrate, whereas $U$. coroides has a larger mouth with a barbel near the tip of the lower jaw, and bites at the substrate more frequently than E. gula does.

Thus, E. gula apparently relies more on vision, whereas $U$. coroides may use mainly tactile cues to detect prey. Similarly, among California nearshore fishes that forage in the sand, the labrid Halichoeres semicinctus (Ayres, 1859) intently inspects the substrate, indicating a reliance on vision to find prey, whereas the ophidiid Chilara taylori (Girard, 1858) apparently detects prey with its barbel-like pelvic fins (Hobson \& Chess, 1986).

The sciaenid Menticirrhus littoralis (Holbrook, 1855) and other benthivorous fishes touch their barbels on the substrate to find prey (Moyle \& Cech Jr., 1982).

In our study, foraging $U$. coroides tilted its body less than did E. gula, a trait which may be related to the ventral position of mouth in the former, as recorded for Menticirrhus saxatilis (Bloch \& Schneider, 1801), whose inferior mouth allow it to dig with few changes in its swimming position (Chao \& Musick, 1977). Both $U$. coroides and E. gula feed on benthic crustaceans, but only E. gula eats polychaetes. This major difference in diet may be related to E. gula visual inspection of substrate and its tubular mouth, which allows it to reach more deeply in the sand.

Both $U$. coroides and E. gula search for prey in an approximately circular area, apparently selecting sites where they forage. This foraging pattern may be related to the spatial distribution of prey, as carnivorous fishes preying on benthic organisms usually search for patches with a greater concentration of prey (Zavala-Camin, 1996), which is in accordance with the optimal foraging theory (Stephens \& Krebs, 1986).
Crustaceans are the main food of the benthivorous fishes from Anchieta Island and are known as a major prey for benthivorous fishes from coastal southern (Haimovici et al., 1989) and northern Brazil (Teixeira \& Helmer, 1997), as well as in South Africa (Booth \& Buxton, 1997). Crustacean availability regulates fish production at West Australia (Edgar \& Shaw, 1995).

The most abundant fish species in our study, the sciaenid $U$. coroides, shows a diet shift from Mysidacea to Amphipoda as it grows. Ontogenetic dietary changes are known for Umbrina canosai (Berg, 1895) (Haimovici et al., 1989), being usually recorded for several other fish species (Cancino \& Castilla, 1988; Gerking, 1994; Booth \& Buxton, 1997). Mysidacea usually swim in midwater, as opposed to the more benthic Amphipoda, associated with sand bottom (Barnes, 1980). Thus, when $U$. coroides turns to Amphipoda, it probably changes its foraging from mid-water to the bottom. Such behavioral change also occurs in a South African sparid fish, Pterogymnus laniarius (Valenciennes, 1830), which occupies reef areas interspersed with sand substrate, and feeds mainly on mysids in midwater as juvenile. When subadult, it turns to prey on benthonic ophiuroids and amphipods (Booth \& Buxton, 1997). On the Western Australian coast, small Upeneichthys stotti Hutchins, 1990 and $U$. lineatus (Bloch \& Schneider, 1801), Mullidae, consume Mysidacea whereas larger individuals prey on larger benthonic organisms, such as carid decapods and brachyuran crabs (Platell et al., 1998). Mysids apparently are an important food item for juveniles of benthivorous marine fishes.

Umbrina coroides and E. gula feed mainly during the morning, whereas T. goodei and T. carolinus concentrate their feeding activity in the afternoon. Such time partitioning in feeding activity may favour species coexistence (Lowe-McConnell, 1977; Ross, 1986), as recorded for reef (Collette $\&$ Talbot, 1972), estuary (Chao \& Musick, 1977) and freshwater (Winemiller, 1989) habitats.

We found that two congener carangids, $T$. goode $i$ and T. carolinus, differ in their main crustacean prey items, respectively Mysidacea and Amphipoda. Differences in diet between sympatric congeners are well known for tropical and subtropical marine fishes (Schmitt \& Coyer, 1982; Platell et al., 1998). In a Northeast Brazilian coastal lagoon, two abundant benthivorous gerreids differ 
in diet composition, with E. gula eating polychaetes, and E. argenteus Baird \& Girard, (1855) showing a more diversified diet, eating also crustaceans and mollusks (Teixeira \& Helmer, 1997). Two embiotocid fishes of the genus Embiotoca prey on Amphipoda crustaceans, each fish species consuming a distinct prey size (Schmitt $\&$ Coyer, 1982). Given the general morphological similarities between congeners, differences in feeding are mainly attributed to resource sharing, thus minimizing competition and allowing multiple species coexistence (Lowe-McConnell, 1987; Gerking, 1994; Platell et al., 1998).

Due to an increase in mouth size, larger fishes consume prey larger than do juveniles (Stergiou \& Fourtouni, 1991; Platell et al., 1998). However, this does not apply to $U$. coroides in our study, as the amphipods consumed by larger individuals are not larger than the mysids taken by smaller fishes. Considering this, the ontogenetic diet shift of $U$. coroides probably evolved as a mean to reduce competition for food both between juveniles and adults, and between juveniles of this sciaenid and the gerreid E. gula, another abundant benthivorous fish which also eats amphipods. Changes in feeding habits in different life stages may reduce the intraspecific and interspecific overlap in food resource use (Winemiller, 1989; Platell et al., 1998). The differences in diet and feeding activity between the benthivorous species here studied may favor the coexistence of the guilds of benthivorous fishes in sandy shores, as already recorded by Hobson \& Chess (1986) in California.

Acknowledgments - We thank R. L. Moura for help in the field; L. F. L. Duarte for help with stomach contents identification, the Instituto Florestal (through M. A. Fontes) for the opportunity to study fishes in the Anchieta Island State Park; the Ibama for collecting permits (46/96 and 57/97); the Fapesp (grant IC 96/12586-2 to PZ), FMB (grant to RAMS), and CNPq (grant 300992/79 to IS) for financial support.

\section{REFERENCES}

BARNES, R. D., 1980, Invertebrate Zoology. Saunders College, Philadelphia.

BOOTH, A. J. \& BUXTON, C. D., 1997, The biology of the panga, Pterogymnus laniarius (Teleostei: Sparidae), on the Agulhas Bank, South Africa. Environmental Biology of Fishes, 49: 207-226.

CANCINO, J. M. \& CASTILLA, J. C., 1988, Emersion behaviour and foraging ecology of the common Chilean clingfish Sicyases sanguineus (Pisces: Gobiesocidae). Journal of Natural History, 22: 249-261.
CHAO, L. N. \& MUSICK, J. A., 1977, Life history, feeding habits and functional morphology of juvenile sciaenid fishes in the York River estuary, Virginia. United States Fishery Bulletim, 75: 657-702.

COLLETTE, B. B. \& TALBOT, F. H., 1972, Activity patterns of coral reef fishes with emphasis on nocturnal-diurnal changeover. In: B.B. Collette \& S.A. Earle (eds.), Results of The Tektite Program: Ecology of Coral Reef Fishes. Science Bulletin 14, Natural History Museum, Los Angeles County.

EDGAR, G. J. \& SHAW, C., 1995, The production and trophic ecology of shallow-water fish assemblages in southern Australia. II. Diets of fishes and trophic relationships between fishes and benthos at Western Port, Victoria. Journal of Experimental Marine Biology and Ecology, 194: 83-106.

GERKING, S. D., 1994, Feeding Ecology of Fish. San Diego Academic Press, California.

HAIMOVICI, M., TEIXEIRA, R. L. \& ARRUDA, M. C., 1989, Alimentação da castanha Umbrina canosai (Pisces: Sciaenidae) no sul do Brasil. Rev. Brasi. Biol., 49: 511522.

HOBSON, E. S. \& CHESS, J. R., 1986, Relationships among fishes and their prey in a nearshore sand community of southern California. Environmental Biology of Fishes, 17: 201-226.

HYSLOP, E. J., 1980, Stomach contents analysis - a review of methods and their application. Journal of Fish Biology, 17: 411-429.

LEHNER, P. N., 1979, Handbook of Ethological Methods. Garland S. T. P. M., New York.

LONGHURST, A. R., 1981, Analysis of Marine Ecosystems. Academic Press, Bedford Institute Of Oceanography, Dartmouth, Nova Scotia.

LOWE-MCCONNELL, R. H., 1977, Ecology of Fishes in Tropical Waters. Studies in Biology, N. 76. Edward Arnold, London, 64p.

LOWE-MCCONNELL, R. H., 1987. Ecological Studies in Tropical Fish Communities. Cambridge Univ. Press, Cambridge, 382p.

MARRERO, C., 1994, Métodos para Cuantificar Contenidos Estomacales em Peces. Universidad De Los Llanos "Ezequiel Zamora", Caracas, 37p.

MCCORMICK, M. I., 1995, Fish feeding on mobile benthic invertebrates: influence of spatial variability in habitat associations. Marine Biology, 121: 627-638.

MOYLE, P. B. \& CECH JR., J. J., 1982, Fishes: An Introduction to Ichthyology. Prentice-Hall, Inc., Englewood Cliffs, 593p.

PLATELL, M. E., POTTER, I. C. \& CLARKE, K. R., 1998, Do the habitats, mouth morphology and diets of the mullids Upeneichthys stotti and U. lineatus in coastal waters of south-western Australia differ? Journal of Fish Biology, 52: 398-418.

SAZIMA, I., 1986, Similarities in feeding behaviour between some marine and freshwater fishes in two tropical communities. Journal of Fish Biology, 29: 53-65. 
SCHMITT, R. J. \& COYER, J. A., 1982, The foraging ecology of sympatric marine fish in the genus Embiotoca (Embiotocidae): importance of foraging behaviour in prey size selection. Oecologia, 55: 369-378.

SOARES, L. S. H., GASAlLA, M. A., RIOS, M. A. T., ARRASA, M. V. \& ROSSI-WONGTSCHOWSKI, C. L. D. B., 1993, Grupos tróficos de onze espécies dominantes de peixes demersais da plataforma continental interna de Ubatuba, Brasil. Publicações Especiais do Instituto Oceanográfico, São Paulo, Brazil, 10: 189-198.

STEPHENS, D. W. \& KREBS, J. R., 1986, Foraging Theory. Princeton Univ. Press, Princeton.

STERGIOU, K. I. \& FOURTOUNI, H., 1991, Food habits, ontogenetic diet shift and selectivity in Zeus faber Linnaeus, 1758. Journal of Fish Biology, 39: 589-603.
TEIXEIRA, R. L. \& HELMER, J. L., 1997, Ecology of young mojarras (Pisces: Gerreidae) occupying the shallow waters of a tropical estuary. Rev. Brasil. Biol., 57: 637-646.

WINEMILLER, K. O., 1989, Ontogenetic diet shifts and resource partitioning among piscivorous fishes in the Venezuelan ilanos. Environmental Biology of Fishes, 26: 177-199.

ZAVALA-CAMIN, L. A., 1996, Introdução aos estudos sobre alimentação natural em peixes. Editora da Universidade Estadual de Maringá, Paraná, Brasil, 129p. 